\title{
Hubungan Penyakit Periodontal pada Ibu Hamil dengan Kejadian Bayi Berat Badan Lahir Rendah (BBLR)
}

\author{
Ratika F. Baliung, Vonny N. S. Wowor, Johanna A. Khoman
}

Program Studi Pendidikan Dokter Gigi Fakultas Kedokteran Universitas Sam Ratulangi, Manado, Indonesia

Email: ratikafbal@gmail.com

Disubmisi: 18 Oktober 2021; direvisi: 23 November 2021; diterima: 25 Desember 2021

\begin{abstract}
Periodontal disease is still one of the dental and oral health disorders that has a high prevalence worldwide. Moreover, it can cause disorders in pregnancy including low birth weight (LBW) infant with the risks of death as well as disorders of growth and development in children. To date, low birth weight is one of the causes of high infant mortality rate. This study was aimed to evaluate the relationship between periodontal disease in pregnant women and the incidence of LBW baby. This was a literature review study searching data on three databases namely Pubmed, ScienceDirect, and Google Scholar and using keywords and a combination of boolean operators. After being selected based on inclusion and exclusion criteria, critical appraisal was conducted, and nine literatures were obtained: cross sectional study, case-control study, cohort study designs. The results showed that the most common periodontal disease in pregnant women was periodontitis. Women who gave birth to LBW babies had poor periodontal conditions compared to women who gave birth to babies with normal weight. Most of the literatures showed a significant relationship between periodontal disease in pregnant women and the incidence of LBW baby. In conclusion, there is a relationship between periodontal disease in pregnant women and the incidence of LBW infant. Periodontitis is one of the risk factors of poor pregnancy outcomes. Keywords: periodontal disease; pregnant women; low birth weight (LBW)
\end{abstract}

\begin{abstract}
Abstrak: Penyakit periodontal masih merupakan salah satu gangguan kesehatan gigi dan mulut dengan prevalensi cukup tinggi di dunia. Dampak penyakit periodontal dapat berupa gangguan pada kehamilan termasuk terjadinya kelahiran bayi berat badan lahir rendah (BBLR) yang berisiko kematian bayi, serta gangguan pertumbuhan dan perkembangan anak. Bayi BBLR merupakan salah satu penyebab tingginya angka kematian bayi (AKB). Penelitian ini bertujuan untuk mengetahui hubungan antara penyakit periodontal pada ibu hamil dengan BBLR. Jenis penelitian ialah suatu literature review dengan pencarian data pada tiga database yaitu Pubmed, ScienceDirect, dan Google Scholar menggunakan kata kunci dan kombinasi boolean operator. Setelah diseleksi berdasarkan kriteria inklusi dan eksklusi, dilakukan critical appraisal, dan didapatkan sembilan literatur dengan desain studi cross sectional, case-control, dan cohort. Hasil penelitian mendapatkan bahwa penyakit periodontal yang terbanyak pada ibu hamil ialah periodontitis. Ibu yang melahirkan bayi BBLR memiliki kondisi periodontal yang buruk dibandingkan ibu yang melahirkan bayi dengan berat badan cukup. Sebagian besar literatur yang ditelaah menunjukkan adanya hubungan bermakna antara penyakit periodontal pada ibu hamil dengan kejadian BBLR. Simpulan penelitian ini ialah terdapat hubungan bermakna antara penyakit periodontal pada ibu hamil dengan kejadian bayi BBLR. Periodontitis merupakan salah satu faktor risiko hasil kehamilan yang buruk.
\end{abstract}

Kata kunci: penyakit periodontal; ibu hamil; berat badan lahir rendah (BBLR) 


\section{PENDAHULUAN}

Kesehatan gigi dan mulut yang terganggu dapat memengaruhi kesehatan seseorang. Berdasarkan data Riset Kesehatan Dasar (RISKESDAS) tahun 2018 prevalensi penduduk yang mempunyai masalah gigi dan mulut di Indonesia mencapai 25,9\%. ${ }^{1}$ Penyakit periodontal merupakan salah satu gangguan kesehatan gigi dan mulut yang mempunyai prevalensi cukup tinggi di dunia. ${ }^{2}$ Pada semua kelompok usia penyakit periodontal memiliki prevalensi sebesar 96,58\%. ${ }^{3}$ Menurut Kementerian Kesehatan Indonesia tahun 2019 penyakit periodontal menempati urutan ke-11 penyakit yang paling banyak terjadi di dunia. ${ }^{4}$ Berdasarkan data RISKESDAS 2018 persentase kasus periodontitis di Indonesia sebesar $74,1 \% .^{4,5}$

Penyakit periodontal merupakan penyakit yang terjadi pada jaringan pendukung gigi, ${ }^{6}$ yang biasanya diawali dengan peradangan pada gingiva. Bila tidak ditangani dengan baik dapat berlanjut menyebabkan gangguan pada jaringan pendukung gigi lainnya. Perubahan hormon pada saat kehamilan sangat memengaruhi kondisi rongga mulut ibu hamil. ${ }^{3}$ Paparan asam lambung dalam rongga mulut dapat menyebabkan peradangan pada gingiva, yang pada akhirnya memengaruhi kehamilan dan perkembangan janin. Perubahan hormon ini seringkali disertai dengan adanya faktor internal dalam rongga mulut seperti adanya plak dan karang gigi. ${ }^{3}$

Peningkatan dan perubahan hormonal saat kehamilan dapat dikatakan sebagai faktor pengubah dan plak bakteri meningkatkan risiko terkena penyakit periodontal selama kehamilan seperti gingivitis kehamilan (pregnancy gingivitis), epulis gravidarum (pyogenic granuloma), dan periodontitis. ${ }^{4}$ Selain itu, penyakit periodontal dapat memengaruhi kesehatan janin dan kondisi kehamilan, termasuk terjadinya kelahiran yang disertai dengan berat badan lahir rendah (BBLR) yang akan membawa risiko kematian, gangguan pertumbuhan dan perkembangan anak, dan risiko anak menjadi stunting jika tidak tertangani dengan baik. ${ }^{3}$ Salah satu penyebab tingginya angka kematian bayi (AKB) ialah bayi BBLR. ${ }^{6}$ Kejadian BBLR dianggap sebagai indikator kesehatan masyarakat karena erat hubungannya dengan angka kematian, kesakitan, dan kejadian kurang gizi di kemudian hari. ${ }^{5}$

Penelitian Retnoningrum melaporkan bahwa kejadian BBLR pada ibu hamil dengan penyakit periodontal 8,75 kali lipat daripada ibu hamil dengan rongga mulut yang sehat. ${ }^{7}$ Hal yang serupa juga dikemukakan oleh Cisse et al yang menyatakan bahwa secara bermakna periodontitis memiliki keterkaitan dengan BBLR. ${ }^{8}$ Berdasarkan data Standar Diagnosis Keperawatan Indonesia (SDKI) angka kejadian BBLR di Indonesia pada tahun 2017 masih relatif tinggi yaitu sebesar $7,1 \% .{ }^{9}$

Berdasarkan latar belakang di atas maka penulis tertarik meninjau lebih lanjut studi pustaka terkait hubungan penyakit periodontal pada ibu hamil dan kejadian BBLR.

\section{METODE PENELITIAN}

Penelitian ini merupakan suatu literature review. Pencarian literatur dalam penelitian ini diperoleh dari database Google scholar, Pubmed, dan Science direct. Pencarian literatur menggunakan keyword dan boolean operator. Literatur diseleksi berdasarkan kriteria inklusi dan eksklusi, selanjutnya dilakukan critical appraisal.

\section{HASIL PENELITIAN}

Sembilan pustaka telah melalui proses reduksi data sesuai dengan kriteria inklusi dan analisis data melalui Joanna Briggs Institute (JBI) critical appraisal yang terdiri dari lima case-control study, tiga crosssectional study, dan satu cohort study.

Tabel 1 memperlihatkan karakteristik dari sembilan pustaka yang digunakan dalam penelitian ini.

Tabel 2 memperlihatkan distribusi gambaran penyakit periodontal pada ibu hamil dengan kejadian BBLR. Penyakit periodontal yang paling sering terjadi pada ibu hamil, yaitu periodontitis.

Tabel 3 memperlihatkan distribusi judul penelitian, desain penelitian, dan rangkuman hasil literatur pada penelitian ini. 
Tabel 1. Karakteristik pustaka

\begin{tabular}{ccccc}
\hline Peneliti dan Tahun & Tempat Penelitian & $\begin{array}{c}\text { Jumlah } \\
\text { Populasi }\end{array}$ & $\begin{array}{c}\text { Jumlah } \\
\text { sampel }\end{array}$ & $\begin{array}{c}\text { Usia sampel } \\
\text { (tahun) }\end{array}$ \\
\hline Ulfah dan Ervina, & Indonesia & 45 & 41 & $15-34$ \\
2016 & & & & \\
Fione, 2012 & Tangerang, Indonesia & 45 & 45 & $17-35$ \\
Calixto et al, 2019 & Maranhão, Brazil & 261 & 86 & $18-35$ \\
Gesase et al, 2018 & Spanyol & 1117 & 156 & $18-40$ \\
Wang et al, 2012 & Taipei, Taiwan & 211 & 113 & $18-40$ \\
Jacob, Nath, 2014 & Malaysia & 340 & 137 & $18-35$ \\
Basha et al, 2015 & India & 307 & 126 & $18-35$ \\
Mega et al 2017 & Kosovo & 200 & 50 & $17-35$ \\
Cisse et al, 2015 & Sénégal & 387 & 126 & $18-35$ \\
\hline
\end{tabular}

Tabel 2. Distribusi gambaran penyakit periodontal pada ibu hamil dengan kejadian BBLR

\begin{tabular}{|c|c|c|c|c|c|}
\hline \multirow[t]{2}{*}{ Peneliti } & \multirow{2}{*}{$\begin{array}{l}\text { Usia Sampel } \\
\text { (tahun) }\end{array}$} & \multirow[t]{2}{*}{ Sampel } & \multirow[t]{2}{*}{ Penyakit periodontal } & \multicolumn{2}{|c|}{ Kelahiran } \\
\hline & & & & BBLR & Normal \\
\hline \multirow{2}{*}{$\begin{array}{l}\text { Ulfah dan } \\
\text { Ervina }^{10}\end{array}$} & $15-34$ & 41 & Periodontitis & 16 & 25 \\
\hline & & & Kehilangan perlekatan klinis & 16 & 25 \\
\hline \multirow[t]{2}{*}{ Fione $^{11}$} & $17-35$ & 45 & Kehilangan perlekatan klinis & 9 & 36 \\
\hline & & & Kedalaman poket peridontal & 9 & 36 \\
\hline Calixto et $\mathrm{al}^{12}$ & $18-35$ & 86 & Periodontitis & 21 & 65 \\
\hline Gesase et $\mathrm{al}^{13}$ & $18-40$ & 156 & Periodontitis & $\begin{array}{c}34 \\
(27,6 \%)\end{array}$ & $\begin{array}{c}122 \\
(13,0 \%)\end{array}$ \\
\hline \multirow[t]{2}{*}{ Wang et $\mathrm{al}^{14}$} & $22-40$ & 113 & Periodontitis & 9 & 47 \\
\hline & & & Gingivitis & 2 & 55 \\
\hline Jacob, Nath ${ }^{15}$ & $18-35$ & 137 & Periodontitis & 90 & 47 \\
\hline Basha et al ${ }^{16}$ & $18-35$ & 126 & Periodontitis & $34,25 \%$ & $18,78 \%$ \\
\hline \multirow[t]{2}{*}{ Mega et al ${ }^{17}$} & $17-35$ & 50 & Periodontitis & 17 & 33 \\
\hline & & & Kedalaman poket periodontal & $\begin{array}{c}2.46 \\
\text { (rerata) }\end{array}$ & $\begin{array}{c}2.27 \\
\text { (rerata) }\end{array}$ \\
\hline Cisse et al ${ }^{18}$ & $18-35$ & 126 & Periodontitis & $89(70 \%)$ & $37(30 \%)$ \\
\hline
\end{tabular}

\section{BAHASAN}

Data yang diperoleh dari sembilan pustaka yang ditelaah menunjukkan bahwa penyakit periodontal yang paling sering terjadi pada ibu hamil yaitu periodontitis. Penelitian oleh Wang et al ${ }^{14}$ membagi sampel dalam tiga kelompok yaitu gingivitis group (GG), periodontitis group (PG), dan healthy group (HG); frekuensi yang tertinggi terdapat pada periodontitis group (PG).

Tabel 3 memperlihatkan bahwa ibu yang melahirkan bayi BBLR memiliki kondisi periodontal yang buruk dan penyakit periodontal dapat menjadi salah satu faktor ibu melahirkan bayi BBLR. Pada penelitian Gesase et al ${ }^{13}$ dijelaskan bahwa wanita yang memiliki penyakit periodontal saat melahirkan memiliki peluang 2,6 lebih tinggi untuk melahirkan bayi dengan BBLR dibandingkan tanpa penyakit periodontal. ${ }^{13}$

Penyakit periodontal yang dialami sebelum kehamilan akan makin memperbesar dan memperparah penyakit tersebut pada masa kehamilan. ${ }^{19}$ Prevalensi penyakit periodontal akan meningkat sesuai dengan usia kehamilan, salah satunya karena kurangnya pemeliharaan kesehatan rongga mulut. Penyakit ini dapat memengaruhi terjadinya kelahiran bayi prematur disertai BBLR maupun kelahiran normal dengan BBLR. ${ }^{20}$ 
Tabel 3. Distribusi judul, desain penelitian dan rangkuman hasil literatur

\begin{tabular}{|c|c|c|c|}
\hline $\begin{array}{c}\text { Penulis dan } \\
\text { Tahun }\end{array}$ & Judul & $\begin{array}{c}\text { Jenis } \\
\text { penelitian }\end{array}$ & Rangkuman hasil \\
\hline $\begin{array}{l}\text { Ulfah dan Ervina, } \\
2016^{10}\end{array}$ & $\begin{array}{l}\text { Hubungan antara periodon- } \\
\text { titis dengan kelahiran bayi } \\
\text { prematur berberat badan lahir } \\
\text { rendah ditinjau dari aspek } \\
\text { destruksi periodontal }\end{array}$ & $\begin{array}{l}\text { Cross- } \\
\text { sectional } \\
\text { observational } \\
\text { study }\end{array}$ & $\begin{array}{l}\text { Terdapat perbedaan tingkat destruksi peri- } \\
\text { odontal antara ibu yang melahirkan bayi } \\
\text { prematur BBLR dan ibu yang melahirkan bayi } \\
\text { normal. Rerata kedalaman poket ibu yang } \\
\text { melahirkan bayi prematur BBLR lebih tinggi } \\
\text { daripada ibu yang melahirkan bayi normal, } \\
\text { namun perbedaan tersebut bersifat numerik saja } \\
\text { dan tidak bermakna secara statistik. }\end{array}$ \\
\hline Fione, $2012^{11}$ & $\begin{array}{l}\text { Kontribusi penyakit peri- } \\
\text { odontal pada ibu hamil terha- } \\
\text { dap BBLR pada Puskesmas } \\
\text { Kecamatan Serpong Kota } \\
\text { Tangerang }\end{array}$ & $\begin{array}{l}\text { Case-control } \\
\text { study }\end{array}$ & $\begin{array}{l}\text { Analisis multivariat menunjukkan bahwa } \\
\text { variabel kedalaman poket pada ibu hamil } \\
\text { berhubungan dengan kejadian berat bayi lahir } \\
\text { rendah (BBLR). }\end{array}$ \\
\hline Calixto et al, $2019^{12}$ & $\begin{array}{l}\text { Detection of periodontal } \\
\text { pathogens in mothers of pre- } \\
\text { term birth and/or low weight }\end{array}$ & $\begin{array}{l}\text { Case-control } \\
\text { study }\end{array}$ & $\begin{array}{l}\text { Tidak ada hubungan bermakna antara bayi } \\
\text { prematur dan bayi berat lahir rendah dengan } \\
\text { patogen periodontal di rongga mulut. }\end{array}$ \\
\hline Gesase et al, $2018^{13}$ & $\begin{array}{l}\text { The association between peri- } \\
\text { odontal disease and adverse } \\
\text { pregnancy outcomes in } \\
\text { Northern Tanzania: A cross- } \\
\text { sectional study }\end{array}$ & $\begin{array}{l}\text { Cross- } \\
\text { sectional } \\
\text { study }\end{array}$ & $\begin{array}{l}\text { Terdapat beberapa simpulan, di antaranya ialah } \\
\text { terdapat hubungan bermakna antara penyakit } \\
\text { periodontal dengan bayi berat lahir rendah } \\
\text { (BBLR) }\end{array}$ \\
\hline Wang et al, $2012^{14}$ & $\begin{array}{l}\text { Association between maternal } \\
\text { periodontal disease and pre- } \\
\text { term delivery and low birth } \\
\text { weight }\end{array}$ & $\begin{array}{l}\text { Cross- } \\
\text { sectional }\end{array}$ & $\begin{array}{l}\text { Terdapat hubungan antara penyakit periodontal } \\
\text { dan kejadian BBLR. }\end{array}$ \\
\hline Jacob, Nath, $2014^{15}$ & $\begin{array}{l}\text { Periodontitis among poor } \\
\text { rural Indian mothers increases } \\
\text { the risk of low birth weight } \\
\text { babies: a hospital-based case } \\
\text { control study }\end{array}$ & $\begin{array}{l}\text { Case control- } \\
\text { study }\end{array}$ & $\begin{array}{l}\text { Ibu yang melahirkan bayi dengan berat badan } \\
\text { rendah memiliki kondisi periodontal yang } \\
\text { buruk dibandingkan dengan ibu yang } \\
\text { melahirkan bayi dengan berat badan cukup. }\end{array}$ \\
\hline Basha et al $2015^{16}$ & $\begin{array}{l}\text { Maternal periodontitis as a } \\
\text { possible risk factorfor preterm } \\
\text { birth and low birth weight }-a \\
\text { prospect }\end{array}$ & $\begin{array}{l}\text { Cohort study } \\
\text { (Prospective } \\
\text { study) }\end{array}$ & $\begin{array}{l}\text { Dari } 307 \text { partisipan, } 126 \text { orang memiliki peri- } \\
\text { odontitis, dan yang melahirkan bayi prematur } \\
\text { sebanyak } 15,87 \% \text {, yang melahirkan bayi } \\
\text { dengan berat badan rendah sebesar } 34,25 \% \text {, dan } \\
\text { ibu yang memiliki penyakit periodontal dan } \\
\text { melahirkan normal sebesar } 18,78 \%\end{array}$ \\
\hline Mega et al $2017^{17}$ & $\begin{array}{l}\text { The association between } \\
\text { periodontal disease and pre- } \\
\text { term low birthweight in } \\
\text { Kosovo }\end{array}$ & $\begin{array}{l}\text { Case-control } \\
\text { study }\end{array}$ & $\begin{array}{l}\text { Ibu yang memiliki periodontitis secara statistik } \\
\text { berisiko } 3,2 \text { kali lebih tinggi untuk melahirkan } \\
\text { anak dengan berat badan rendah dan } 3,4 \text { kali } \\
\text { lebih tinggi melahirkan bayi prematur, diban- } \\
\text { dingkan dengan ibu tanpa periodontitis. Ibu } \\
\text { yang melahirkan bayi berat badan rendah } \\
\text { memiliki poket periodontal yang lebih dalam. }\end{array}$ \\
\hline Cisse et al, $2015^{18}$ & $\begin{array}{l}\text { Periodontal disease of preg- } \\
\text { nant women and low weight } \\
\text { newborn in Senegal: a case- } \\
\text { control study }\end{array}$ & $\begin{array}{l}\text { case-control } \\
\text { study }\end{array}$ & $\begin{array}{l}\text { Proporsi ibu dengan periodontitis yang mela- } \\
\text { hirkan bayi berat badan rendah } 70 \% \text {, sedangkan } \\
\text { ibu dengan periodontitis yang melahirkan bayi } \\
\text { dengan berat badan normal sebesar } 30 \% \text {. } \\
\text { Periodontitis secara bermakna terkait dengan } \\
\text { berat badan rendah disesuaikan dengan usia, } \\
\text { BMI dan indeks periodontal lainnya. }\end{array}$ \\
\hline
\end{tabular}

Berdasarkan Tabel 2, terdapat tujuh penelitian yang menunjukkan adanya hubungan antara penyakit peridontal dengan kejadian BBLR, sedangkan dua di antaranya menjelaskan bahwa tidak terdapat hubungan antara penyakit periodontal dan BBLR.

Penelitian Ulfah dan Ervina ${ }^{10}$ menjelaskan bahwa tidak terdapat hubungan antara 
periodontitis dengan kejadian bayi BBLR. Menurut peneliti, ${ }^{10}$ hal ini kemungkinan disebabkan oleh jumlah sampel yang terlalu sedikit serta jumlah sampel antara ibu yang melahirkan bayi prematur BBLR dan ibu yang melahirkan bayi normal tidak seimbang. Namun, peneliti juga menjelaskan bahwa terdapat perbedaan tingkat destruksi periodontal dan kehilangan perlekatan antara ibu yang mengalami BBLR dengan ibu yang melahirkan normal.

Hal serupa juga dilaporkan pada penelitian Calixto et $\mathrm{al}^{12}$ yang menyatakan bahwa tidak terdapat hubungan bermakna antara penyakit periodontal dengan kelahiran prematur maupun BBLR, namun Calixto et $\mathrm{al}^{12}$ menjelaskan bahwa periodontitis dapat menyebabkan faktor penyebab kelahiran prematur dan BBLR dengan Odds Ratio (OR) berkisar antara 2,09-4,19.

Tabel 2 juga memperlihatkan bahwa kejadian ibu dengan bayi BBLR lebih sedikit dibandingkan dengan ibu yang melahirkan normal, tetapi pada penelitian dijelaskan bahwa terdapat hubungan bermakna dengan tingkat kemaknaan 95\% dan OR sehingga dapat disimpulkan bahwa kedua variabel ini memiliki hubungan.

Terdapat beberapa faktor yang mendasari adanya perbedaan pada setiap penelitian, antara lain dalam hal faktor risiko seperti rendahnya keadaan sosial-ekonomi, pendidikan, etnis, status gizi, sikap dan perilaku, serta penyakit sistemik juga bertanggung jawab terhadap kelahiran bayi dengan BBLR yang turut memengaruhi hasil penelitian.

Penelitian terkini menunjukkan adanya hubungan antara penyakit periodontal dengan kejadian BBLR yang terjadi sebagai hasil infeksi dan dimediasi secara tidak langsung. ${ }^{10}$ Hubungan antara kehamilan dan penyakit periodontal merupakan hubungan dua arah dimana yang satu memengaruhi yang lainnya. Faktor utama yang memengaruhi ialah adanya plak bakteri yang didukung oleh perubahan hormonal pada masa kehamilan, dan faktor risiko yang berhubungan dengan kedua variabel ini. ${ }^{21,22}$

\section{SIMPULAN}

Terdapat hubungan bermakna antara penyakit periodontal pada ibu hamil dengan kejadian bayi berat badan lahir rendah (BBLR). Selain itu, periodontitis merupakan salah satu faktor risiko hasil kehamilan yang buruk.

\section{Konflik Kepentingan}

Penulis menyatakan tidak terdapat konflik kepentingan dalam studi ini.

\section{DAFTAR PUSTAKA}

1. Farani W, Abdillah MI. Prevalensi maloklusi anak usia 9-11 tahun di SD IT Insan Utama Yogyakarta. Insisiva Dent J (Maj Kedokt Gigi Insisiva). 2021;10(1):26-31.

2. Genco RJ, Borgnakke WS. Risk factors for periodontal disease. Periodontol. 2013; 62(1):59-94.

3. Tyas W, Susanto H, Adi M, Udiyono A. Gambaran kejadian penyakit periodontal pada usia dewasa muda (15-30 tahun) di Puskesmas Srondol Kota Semarang. J Kesehat Masy Univ Diponegoro. 2016; 4(4):510-3.

4. Haryanto R. Meningkatkan pengetahuan cara menggosok gigi dengan baik dan benar melalui penyuluhan pada anak. J Kreat Pengabdi Kpd Masy. 2021;4:396-9.

5. Kementerian Kesehatan RI. Kesehatan Gigi Nasional September 2019. Pusdatin Kemenkes RI. 2019; p. 1-6.

6. Novitasari A, Hutami MS, Pristya TYR. Pencegahan dan pengendalian BBLR di Indonesia: systematic review. Cochrane Database Syst Rev [Internet]. 2020;2(3): 175-82. Available from: http://doi. wiley.com/10.1002/14651858.CD0135 74

7. Apriliani A, Ervina, Irma, Daliemunthe SH. Hubungan antara periodontitis dengan kelahiran bayi prematur berberat badan lahir rendah dari aspek keparahan inflamasi gingiva. 2011. Available from: http://repository.usu.ac.id/handle/12345 $6789 / 25405$

8. Syafar I, Tahir H, Oktawati S. The correlations between periodontal disease in the woman with pregnancy and low birth weight infant: a systematic review. MDJ (Makassar Dent Journal) [Internet]. 2019;8(3):180-4. Available from: http: //www.pdgimakassar.org/jurnal/index.p 
hp/MDJ/article/view/296

9. Mayasari E, Prasetya Balebu GP, Hasanah L, Wulandari R, Nooraeni R. Analisis determinan berat badan lahir rendah (BBLR) di Provinsi Nusa Tenggara Timur tahun 2017. Bus Econ Commun Soc Sci J. 2020;2(2):233-9.

10. Ulfah K, Ervina I. Hubungan antara periodontitis dengan kelahiran bayi prematur berberat badan lahir rendah ditinjau dari aspek destruksi periodontal. Cakradonya Dent J. 2016;8(1):1-76..

11. Fione VR. Kontribusi penyakit periodontal pada ibu hamil tehadap BBLR pada Puskesmas Kecamatan Serpong Kota Tanggerang. JIK. 2011;7(1):62-9.

12. Calixto NRV, Alves CMC, Abreu LMG, Thomaz EBAF, Vidal FCB, Filho ISG, et al. Detection of periodontal pathogens in mothers of preterm birth and/or low weight. Med Oral Patol Oral y Cir Bucal. 2019;24(6):e776-81.

13. Gesase N, Miranda-Rius J, Brunet-llobet L, Lahor-Soler E, Mahande J, Masenga G. The association between periodontal disease and adverse pregnancy outcomes in Northern Tanzania: a crosssectional study. Afr Health Sci. 2018; 18(3):501-11.

14. Wang Y, Liou J, Pan W. Association between maternal periodontal disease and preterm delivery and low birth weight. Taiwan J Obstet Gynecol [Internet]. 2013;52(1):71-6. Available from: http:// dx.doi.org/10.1016/j.tjog.2013.01.011

15. Jacob PS, Nath S. Periodontitis among poor rural Indian mothers increases the risk of low birth weight babies: a hospitalbased case control study. J Periodontal Implant Sci. 2014;44(2):85-93.

16. Basha S. Maternal periodontitis as a possible risk factor for preterm birth and low birth weight - . 2015;13(6):537-44. Oral Health Prev Dent. 2015;13(6):537-44. Doi: 10.3290/j.ohpd.a34053.

17. Mega K, Dragidella F, Disha MZS, Sllamniku DZ. The association between periodontal disease and preterm low birthweight in Kosovo. Acta Stomatol Croat. 2017; 51(1):33-40. Doi: 10.15644/asc51/1/4.

18. Cisse D, Diouf M, Faye A, Diadhiou MF, TalDia A. Periodontal disease of pregnant women and low weight newborn in Senegal: a case-control study. Open Journal of Epidemiology. 2015;5:1-8.

19. Suwandi T. Hubungan penyakit periodontal pada kehamilan dengan kelahiran bayi prematur. J Trisakti [Internet]. 2019;1: 53-7. Available from: https://trijurnal. lemlit.trisakti.ac.id/jkgt/article/view/51 59

20. Soulissa GA. Hubungan kehamilan dan penyakit periodontal (Relationship between pregnancy and periodontal disease). J PDGI. 2014;63(3):71-7.

21. Reyes GLE. Pengetahuan pemeliharaan kesehatan gigi dan mulut dan status kesehatan periodontal. J Chem Inf Model. 2013;53(9):1689-99.

22. Hatta M. Penyakit periodontal dan hubungannya dengan aterosklerosis [Skripsi]. Makassar: Universitas Hasanuddin; 2011. 